\title{
Non-invasive treatment of uterine fibroids using MR guided high intensity focused ultrasound: results on quality of life, non-perfused volume ratio and size reduction over 12 months
}

\author{
Federica Ciolina ${ }^{*}$, Fabrizio Boni, Fulvio Zaccagna, Luca Bertaccini, Beatrice Cavallo Marincola, Vincenzo Noce, \\ Carola Palla, Alessandro Napoli, Carlo Catalano
}

From 2nd European Symposium on Focused Ultrasound Therapy

Rome, Italy. 10-11 October 2013

\section{Purpose}

To evaluate the efficacy of MR guided acoustic ablation in symptoms relief and volume reduction over time.

\section{Materials and method}

110 leiomyomas in 98 women (average age 39,3 years) were treated with MRI-guided focused ultrasound (MRgFUS). The treatment is carried out using the ablative properties of the HIFU system under 3T MRI guide. Symptoms (e.g. menorrhagia, pelvic pain) were scored using Severity Score (SS) and quality of life was determined using the UFS-QOL score. Pre-treatment measurementes of leiomyoma volume were obtained by MR images. Immediately after treatment, Non-perfused Volume (NPV) was calculated from T1-w contrastenhanced MR sequences. The average volume of treated fibroids was $90.27 \pm 90.4 \mathrm{~mm} 3$. Follow-up images were obtained at 3 and 12 months after treatment and served to determine leiomyoma shrinkage. Qualitative and quantitative relations between fibroid volume, NPV ratio at treatment, and 12-month shrinkage were measured.

\section{Results}

MRgFUS treated patients demonstrated a significant change in USF-QoL score: mean SS score values were $48.6 \pm 13.4$ (pre-treatment), $25.1 \pm 8.9$ (three-months follow-up) and 19,3 6.8 (twelve-months follow-up). Fibroids volume changed from $90.27 \pm 90.4 \mathrm{~mm} 3$ (before treatment) to $54 \pm 66.1 \mathrm{~mm} 3$ (at 12 months follow up).

\footnotetext{
Department of Radiological Sciences, Oncology and Pathology, Sapienza
} University of Rome, Italy
Submit your next manuscript to BioMed Central and take full advantage of:

- Convenient online submission

- Thorough peer review

- No space constraints or color figure charges

- Immediate publication on acceptance

- Inclusion in PubMed, CAS, Scopus and Google Scholar

- Research which is freely available for redistribution

Submit your manuscript at 